\title{
気孔を含んだアルミナセラミックスの熱衝撃破壊挙動
}

\author{
芦塚正博 · 石田英一* \\ 九州工業大学大学院生命体工学研究科生体機能専攻, 804-8550 北九州市戸畑区仙水町 1-1 \\ *九州工業大学工学部物質工学科, 804-8550 北九州市戸畑区仙水町 1-1
}

\section{Thermal Shock Fracture Behavior of Alumina Ceramics Containing Pores}

\author{
Masahiro ASHIZUKA and Eiichi ISHIDA*
}

Department of Biological Function and Engineering, Graduate School of Life Science and System Engineering, Kyushu Institute of Technology, 1-1, Sensui-cho, Tobata-ku, Kitakyushu-shi 804-8550

*Department of Materials Science and Engineering, Faculty of Engineering, Kyushu Institute of Technology,

1-1, Sensui-cho, Tobata-ku, Kitakyushu-shi 804-8550

\begin{abstract}
Thermal shock fracture behavior of alumina ceramics containing pores was studied by measuring strength after water-quenching. The thermal shock fracture behavior was evaluated by a critical temperature difference $\left(\Delta T_{\mathrm{c}}\right)$ and a survival strength $\left(\sigma_{\mathrm{r}}\right)$ after water-quenching test. The critical temperature difference increased with increasing porosity. On the other hand, an influence of pore size could not be recognized. From the comparison between measured and estimated values, it was suggested that an increase in critical temperature difference was originated from the adiabatic effect by air bubbles generating at surface pores. The survival strength after water-quenching test increased with increasing pore size, but increase became smaller in pore sizes over $10 \mu \mathrm{m}$. The reciprocal of squared survival strength could be related with the elastic strain energy stored up to fracture.

[Received May 30, 2002; Accepted August 9, 2002]
\end{abstract}

Key-words : Thermal shock behavior, Porous material, Porosity, Pore size, Alumina, Critical temperature difference, Thermal stress resistance, Thermal damage resistance

\section{1. 緒 言}

多孔質材料は，軽量性，断熱性，選択的透過性といったさま ざまな機能を有している．多孔質材料の選択的透過性及びセラ ミックスの耐熱性を利用して，多孔質セラミックスを高温集塵 フィルターあるいは耐火断熱材として使用が可能である. その ような，高温領域での利用に際しては，急激な加熱あるいは冷 却の過程を伴う場合がしばしば生じるため, 熱衝撃破壊挙動を 明らかにすることが重要である.

セラミックスの熱衝撃破壊挙動に関してはこれまでにも種々 の方面からの研究がなされている．緻密なアルミナセラミック スの熱衝撃破壊挙動については多くの報告があるが1) 5)，多孔 質材料の熱衝撃破壊に関する研究は少ない6) 10).

著者ら ${ }^{11)}$ は気孔を含んだ焼結セラミックスの弾性率，強度 及び破壊勒性值を測定し，それらの機械的特性に気孔率のみな らず，気孔径も影響することを既に報告した．本報告では，気 孔を含んたセラミックスの熱衝撃破壊挙動を測定し，気孔率及 び気孔径の影響を検討した。

セラミックスへ熱衝撃を与える方法には，一般に水中急冷法 がとられている. 水中急冷法では急冷の際に試料表面で気泡が 発生し，熱伝達係数 $h$ へ大きく影響すると推測され，熱衝撃 破壊挙動の解析を複雑にしている．気泡の発生を避けるため に，冷却媒体としてセラミックス微粉末の流動層を使用する方 法 ${ }^{12)}$, 低融点金属 $\left(\mathrm{Na}: \text { 融点 } 97.8^{\circ} \mathrm{C}, \mathrm{Sn}: \text { 融点 } 231.9^{\circ} \mathrm{C}\right)^{13)}$ 15) を利用することが考えられる，また，気泡発生の影響を最小に するために試験片の先端部を円錐にすることも試みられてい る15). しかし，これらの方法は実験上の多くの困難を伴う. 一方, 水中急冷法は多くの熱衝撃破壊の研究で採用されてお り，データの比較ができる可能性があることより，また，気泡 発生の熱伝達係数 $h$ に対する影響は, 同一形状, 同一寸法の 試料を用いることにより一定とでき，相対比較が可能であると 考えている，また，実験上の簡便さ等も考え併せ，本研究では
水中急冷法を採用した ${ }^{16)}$.

\section{2. 実験方法}

アルミナ粉末と黒鉛粉末をエタノールを溶媒としてボールミ ルで混合し，乾燥させて混合原料粉末とした．その混合原料粉 末を金型で予備成形した後, CIP で本成形 (プレス圧 $150 \mathrm{MPa}$ ) し， $1550^{\circ} \mathrm{C}$ で $2 \mathrm{~h}$ 焼成して気孔率が一定（10及び $20 \%$ ）で気 孔径の異なる試料を作製した。気孔率及び気孔径は粒径の異な る黒鉛粉末を使用することにより制御した．本研究で使用した 試料は緻密試料（N0） と気孔率が $10 \%$ で最大気孔径が $8.5 \mu \mathrm{m}$ (A10)，19 $\mu \mathrm{m}$ （B10）及び $34 \mu \mathrm{m} （ \mathrm{C} 10 ）$ の試料及び気孔率が $20 \%$ で最大気孔径が $12 \mu \mathrm{m}(\mathrm{A} 20), 21 \mu \mathrm{m}$ （B20）及び $44 \mu \mathrm{m}$ (C20) の試料の 7 種である.これらの試料の最大気孔径とし ては鏡面にした試料表面の気孔を走査型電子顕微鏡 (SEM) で観察して棈円近似し, 長軸と短軸の長さの平均値より求めた 気孔径の中で最大のものを用いた。これらの試料は機械的性質 の測定に使用したものと同じ方法で作製したので，その微細構 造, 気孔径分布等の詳細は省略し, 本研究で関係する物性值等 のみを表 1 に示した ${ }^{11)}$.

試料の大きさは $3 \times 3 \times 40 \mathrm{~mm}$ である. 試料は大気中, 昇温 速度 $5^{\circ} \mathrm{C} / \mathrm{min}$ で加熱し, 所定の温度に $20 \mathrm{~min}$ 加熱した後, $20^{\circ} \mathrm{C}$ に保持した水中へ落下することにより急冷して熱衝撃を与え た. 急冷後の試料を染色浸透液へ漬け, 目視で最大亀裂を探 し, 最大亀裂を含む面を引張り面として 4 点曲げで残留強度 を求めた.

\section{3. 結果及び考察}

緻密試料の測定結果を図 1 に示す. 横軸は試料加熱温度と冷 却媒体である水の温度の差で, 急冷温度差 $\Delta T$ と呼ばれるも のである. 縦軸は急冷した後に測定した曲げ強度である. 測定 結果は，一般に報告されている結果とほとんど同じ傾向を示 
Table 1. Symbol, Porosity, Grain Sizes, Pore Sizes and Young's Modulus

\begin{tabular}{cccccc}
\hline Symbol & $\begin{array}{c}\text { Porosity } \\
/ \%\end{array}$ & $\begin{array}{c}\text { Grain size } \\
/ \mu \mathrm{m}\end{array}$ & $\begin{array}{c}\text { Maximum } \\
\text { pore size } \\
/ \mu \mathrm{m}\end{array}$ & $\begin{array}{c}\text { Young's } \\
\text { modulus } \\
/ \mathrm{GPa}\end{array}$ \\
\hline $\mathrm{N} 0$ & $0.9 \pm 0.3$ & $1.20 \pm 0.35$ & 1.6 & 363 & \pm 1 \\
\hline $\mathrm{A} 10$ & $11.8 \pm 0.4$ & $1.19 \pm 0.30$ & 8.5 & 270 & \pm 3 \\
$\mathrm{~B} 10$ & $11.7 \pm 0.4$ & $1.09 \pm 0.23$ & 19 & 274 & \pm 5 \\
$\mathrm{C} 10$ & $10.9 \pm 0.3$ & $1.23 \pm 0.27$ & 34 & 281 & \pm 3 \\
\hline $\mathrm{A} 20$ & $19.7 \pm 0.4$ & - & 12 & 203 & \pm 6 \\
$\mathrm{~B} 20$ & $19.4 \pm 0.3$ & - & 21 & 206 & \pm 7 \\
$\mathrm{C} 20$ & $19.4 \pm 0.3$ & - & 44 & 212 & \pm 3 \\
\hline
\end{tabular}

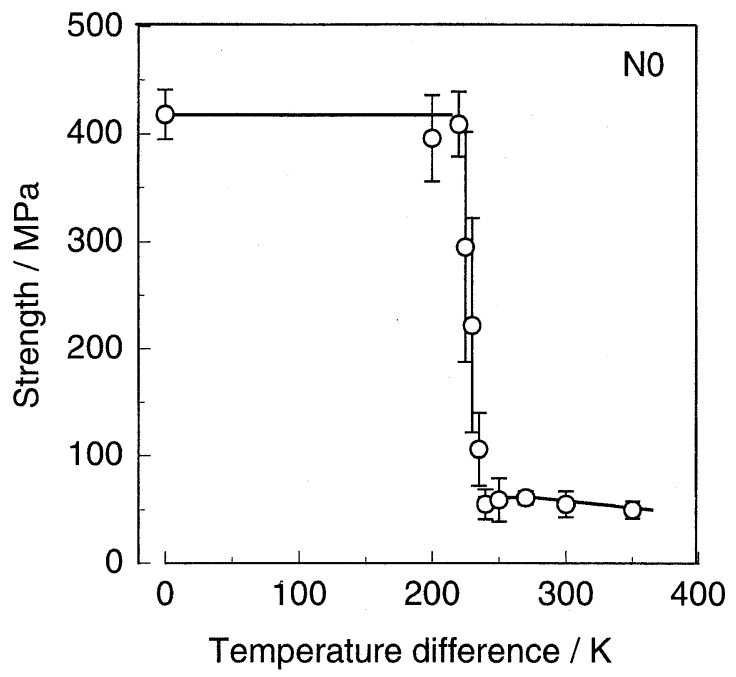

Fig. 1. Room-temperature strength of dense alumina as a function of quenching temperature difference.

し, $220^{\circ} \mathrm{C}$ から $235^{\circ} \mathrm{C}$ 間で急激に強度低下を示した。急激に 強度低下を示す温度が臨界温度差 $\Delta T_{\mathrm{c}}$ である。

図 2 は気孔率が $10 \%$ と $20 \%$ で，気孔径が小，中及び大の試 料についての結果であるが，全体的な傾向は，気孔率が $10 \%$ の試料も20\%の試料も緻密試料に類似した傾向を示した.こ れらの傾向は臨界温度差 $\Delta T_{\mathrm{c}}$ と, 熱衝撃破壊したあとの残存 強度 $\sigma_{\mathrm{r}}$ で特徵づけることができる. 本研究では, 臨界温度差 $\Delta T_{\mathrm{c}}$ としては急激に強度低下を開始する温度と, 急激な強度 低下が終わった温度を $5^{\circ} \mathrm{C}$ 間隔で読みとり，それらの温度の中 間値を臨界温度差とした。

図 3 は気孔率が $10 \%$ 及び $20 \%$ の試料について, 臨界温度差 と最大気孔径の関係で整理したものです．緻密試料と $10 \%$ 気 孔率の試料での臨界温度差 $\Delta T_{\mathrm{c}}$ は緻密試料の $\Delta T_{\mathrm{c}}$ より僅かに 増加した. 気孔率が $10 \%$ から $20 \%$ へと増加すると臨界温度差 は更に高くなった。しかし，気孔率が $10 \%$ から $20 \%$ の試料共 に気孔径の影響は認められなかった。

一般に, 臨界温度差 $\Delta T_{\mathrm{c}}$ と材料強度 $\sigma$, 膨張係数 $\alpha$, ヤング 率 $E$ の間には次のような関係がある.

$$
\Delta T_{\mathrm{c}}(\text { estimated })=\frac{\sigma}{\alpha E}
$$

（1）式を用いて測定結果を整理したのが図 4 である。なお，

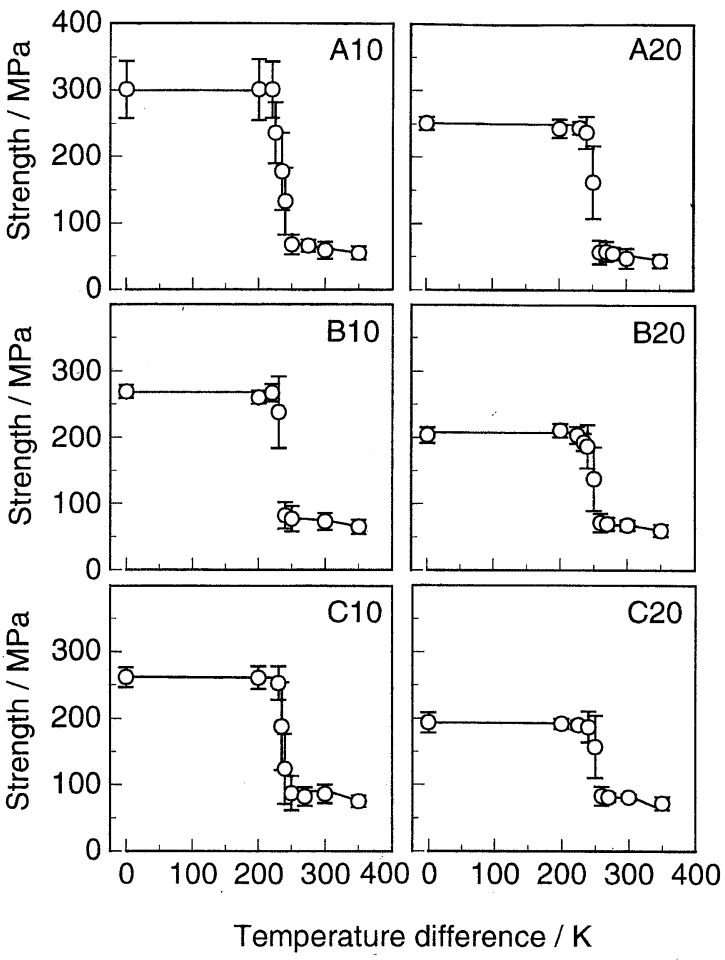

Fig. 2. Room-temperature strength fracture of alumina containing pores as a function of quenching temperature.

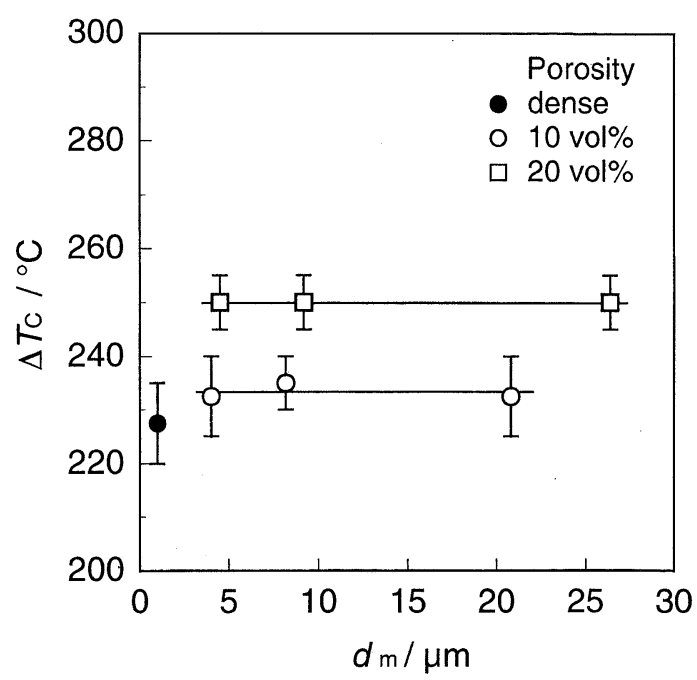

Fig. 3. Relation of critical quenching temperature difference $\Delta T_{\mathrm{c}}$ and the greatest pore size $d_{\mathrm{m}}$.

(1)式で定量的な計算をする場合には $\sigma$ の值として引張強度を 使用しなけれげならない. 引張強度 $\sigma_{\mathrm{t}}$ と 4 点曲げ強度 $\sigma_{4 \mathrm{P}}$ の 間には次のような関係がある。

$$
\frac{\sigma_{4 \mathrm{P}}}{\sigma_{\mathrm{t}}}=\left\{\frac{6(m+1)^{2}}{m+3}\right\}^{1 / m}
$$

ワイブル係数 $m$ は明らかでないが, $m$ が一定であると引張強 度 $\sigma_{\mathrm{t}}$ と 4 点曲げ強度 $\sigma_{4 \mathrm{P}}$ の間には一定の関係がある. 本研究 の場合, 測定值 $\Delta T_{\mathrm{c}}$ (measured) と (1) 式から推測した $\Delta T_{\mathrm{c}}$ (estimated) の対応性を明らかにすることが目的であるため, $\sigma$ の值には $m=10$ と仮定して求めた推測引張強度を使用した. 


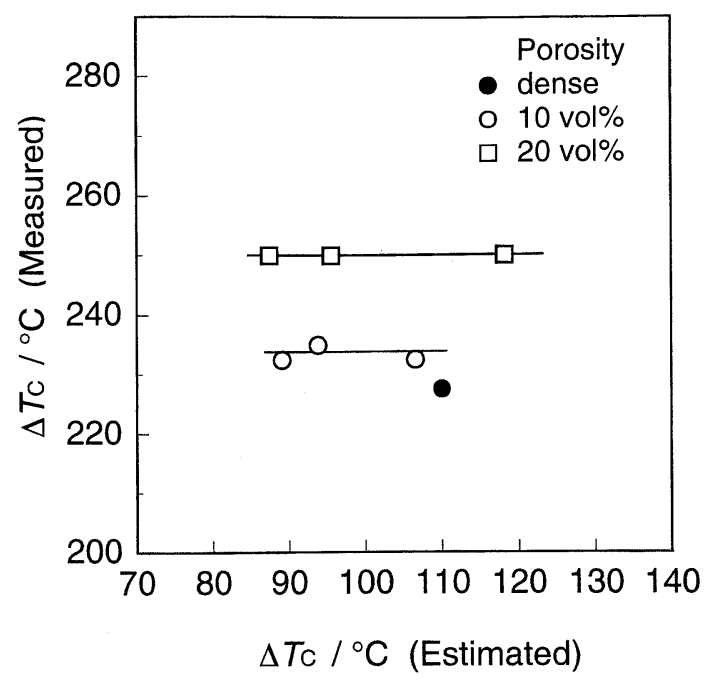

Fig. 4. Comparison of observed and estimated values for critical quenching temperature difference $\Delta T_{\mathrm{c}}$ of alumina containing pores.

図 4 より明らかなように測定値 $\Delta T_{\mathrm{c}}$ (measured） と(1)式から 推測した $\Delta T_{\mathrm{c}}$ (estimated) との間には相関性は認められな かった. 多孔質材料の水中急冷の場合, 試料表面で発生する気 泡による断熱効果により急冷状態が穏やかになる．このような 場合には(1)式を補正する必要がある。

$$
\Delta T_{\mathrm{c}}(\text { estimated })=\frac{\sigma_{\mathrm{f}}}{\alpha E} f(\beta)
$$

$f(\beta)$ は熱衝撃の程度を表すもので，(4)式で表されるビオ係 数 $\beta$ の関数として (5) 式が提案されている17) 19).

$$
\begin{aligned}
& \beta=\frac{b h}{k} \\
& f(\beta)=1.5+\frac{A}{\beta}-0.5 \exp \left(-\frac{B}{\beta}\right)
\end{aligned}
$$

ここで, $h$ は熱伝達係数, $k$ は試料の熱伝導度, $b$ は試料寸法 因子である。 また，(5)式中の A, B は試験片の形状により決 まる定数である. 本研究のように, 水中急冷の場合にはビオ係 数 $\beta$ は非常に大きくなるため，(5) 式は $f(\beta)$ と近似でき，(1) 式が導かれる. 一方, 多孔質材料の急冷に水を使用する場合に は，試料表面で気泡が発生することになる ${ }^{19), 20)}$. 試料表面に 気泡が発生すると, 気泡による断熱効果のために熱伝達係数 $h$ へ大きな影響を与えると推測される. 気泡の断熱効果が顕著に なり，急冷現象が緩和されるようになると(5)式は次のように 近似できる。

$$
f(\beta)=\frac{A}{\beta}=\frac{A}{b} \cdot \frac{k}{h}
$$

本研究は同一試料形状の試料での測定であるので, $b$ は一定と 仮定でき，(6)式を(2)式に代入すると，次のようになる.

$$
\left.\Delta T_{\mathrm{c}} \text { (estimated }\right)=\frac{\sigma}{\alpha E} \cdot \frac{A}{\beta} \propto \frac{\sigma}{\alpha E} \cdot \frac{k}{h}
$$

急冷に際して発生する気泡の量が多いほど断熱効果が大きく なる. 気孔率が $10 \%$ の試料より $20 \%$ の方が試料表面での気孔 の占める割合が大きいため発生する気泡の量は多くなり, 断熱 効果が顕著になる，すなわち，気孔率が $10 \%$ の試料より $20 \%$ の方が熱伝達係数 $h$ は小さくなると推測される. Becher ら ${ }^{19)}$ 、及びSingh ら ${ }^{20)}$ は冷却媒体として水を使用した場合の熱伝達 係数 $h$ と試料と冷却媒体の温度差 $\Delta T$ の関係について考察し ている. 図 5 は Becher ら ${ }^{19)}$ がまとめた熱伝達係数 $h$ と急冷温

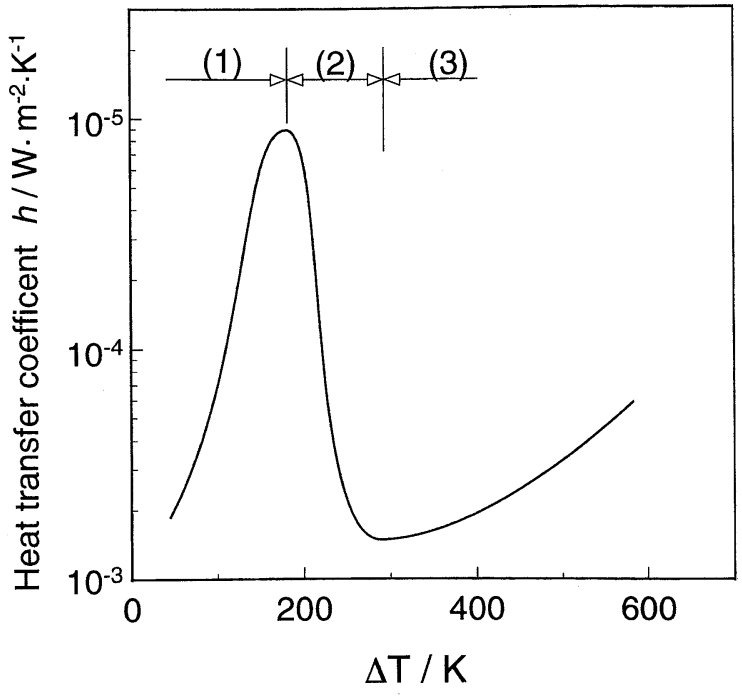

Fig. 5. Heat transfer coefficient $h$ as a function of quenching temperature difference $\Delta T$.

(a) Covection with nucleate boiling, (b) film formation, (c) radiation effects.

度差 $\Delta T$ の関係である．この結果は膜形成領域での熱伝達係 数 $h$ はわずかな気泡膜の増加でも一けた程度低下することを 示している. 一方, 材料の熱伝導度 $k$ と気孔率の関係について は多く式が提案されている21),22). Kuniii ${ }^{23)}$ 及び Saegusa ら ${ }^{24)}$ 結果を参考にすると，気孔率が $10 \%$ 増加すると，熱伝導率は $13 \%$ 程度低下すると推測される. 現在のところ, 気孔率が $10 \%$, $20 \%$ と増加した場合の熱伝達係数の低下の程度が明らかでな いが，図 5 から熱伝導度の低下の程度より大きいと推測して いる. すなわち, 本研究で使用した多孔質材料の場合, (4) 式 で示したビオ係数 $\beta$ には熱伝導度 $k$ より, 熱伝達係数 $h$ の值 の変化の影響が大きいと推測している. 図 4 で測定值 $\Delta T_{\mathrm{c}}$ （measured） と推測値 $\Delta T_{\mathrm{c}}$ （estimated）の間に相関性が認め られなかったのは，気孔率が $10 \%$ から $20 \%$ へと変化すると熱 伝達係数 $h$ の低下の影響が大きかったためビオ係数 $\beta$ が小さ くなり，(7)式の臨界温度差 $\Delta T_{\mathrm{c}}$ (estimated）が大きくなった ためと考えられる.

図 6 (a) は熱衝撃破壊後の残存強度を気孔径で整理したもの である. $10 \%$ 及び $20 \%$ 気孔率の試料について，気孔径が大き くなるとともに残存強度は大きくなり，気孔径が $20 \mu \mathrm{m}$ 以上に なると増加の程度が小さくなり一定の值を示す傾向があった。 また， $20 \%$ の試料より，10\%の試料の残存強度が高くなって いるが，緻密試料との関係が明瞭でない.

図 6(b)は, 縦軸に熱衝撃破壊後の残存強度を熱衝撃前の材 料強度で割った值をとって整理し直したものである.この場合 の縦軸は熱衝撃を与えた後の残存強度の熱衝撃を与える前の材 料強度に対する割合を示している.すなわち, 縦軸の值が大き いほど, 熱衝撃破壊後の強度低下の割合が少ないことを示して いる.このようななとめ方をすることにより, 緻密試料, 10\% 気孔率, $20 \%$ 気孔率の試料が統一した傾向でまとめることが できた.すなわち, 維密試料から気孔径が $20 \mu \mathrm{m}$ 程度までは気 孔径が大きくなると気孔率には関係なく強度低下の割合が減少 するが, 気孔径が $20 \mu \mathrm{m}$ 以上では気孔率の高い試料の方が強度 低下の割合が少なくなった。

Hasselmanの熱衝撃破壊統一理論 (unified theory of thermal shock fracture) によれば, 内在する亀裂の長さ $l_{0}$ が小さ 

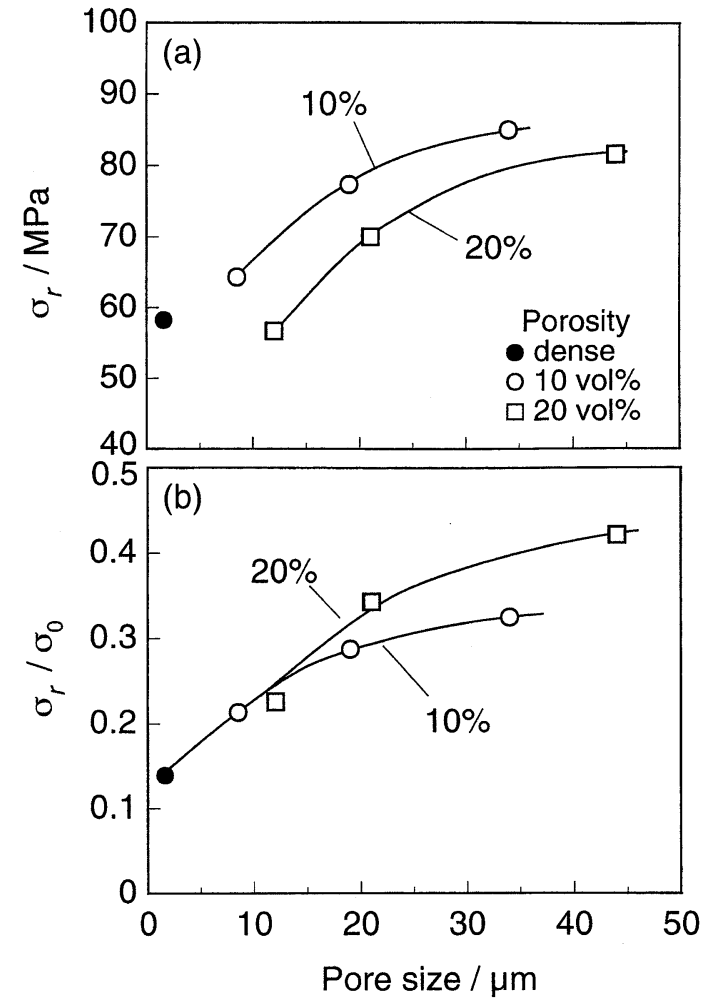

Fig. 6. Survival strength $\sigma_{\mathrm{r}}$ or degradation proportion of that to initial strength $\sigma_{0}$ as a function of the greatest pore size.

い試料での catastrophic な破壊をした後の亀裂長さ $l_{\mathrm{f}}$ は

$$
l_{\mathrm{f}}=\frac{1}{4 \pi N l_{0}}
$$

となる2),3)

一方, 長さ $2 l_{0}$ の亀裂を含む材料の破壊強度 $\sigma_{0}$ は

$$
\sigma_{0}=\left(\frac{2 E \gamma}{\pi l_{0}}\right)
$$

となる（9)式の $l_{0}$ を(8)式へ代入すると

$$
l_{\mathrm{f}}=\frac{1}{4 \pi N l_{0}}=\frac{\sigma_{0}{ }^{2}}{8 \pi \gamma E_{0}}=\left(\frac{1}{4 \pi \gamma}\right)\left(\frac{\sigma_{0}{ }^{2}}{2 E_{0}}\right)
$$

一方, catastrophic な破壊をした後の破壊強度 $\sigma_{\mathrm{r}}$ と破壊起点 での亀裂長さ $l_{\mathrm{r}}$ の間には，次のような式が導かれる.

$$
K_{\mathrm{IC}}=Y \sigma_{\mathrm{r}} \sqrt{l_{\mathrm{r}}} \quad \therefore \quad l_{\mathrm{r}}=\frac{1}{Y} \frac{K_{\mathrm{IC}}}{\sigma_{\mathrm{r}}{ }^{2}}
$$

著者ら ${ }^{11)}$ は気孔を含んだアルミナセラミックスの機械的性質 を測定し, 破壊起点での亀裂の大きさ $l_{\mathrm{r}}$ は最大気孔径 $d_{\mathrm{m}}$ より 気孔率 $10 \%$ の試料で 10 倍以上, 気孔率 $20 \%$ の試料では 13 倍以 上大きかったが，気孔径が大きくなると，更に増大することを 明らかにした。すなわち， $l_{\mathrm{r}}$ は熱衝撃破壊をした後の最終亀裂 長さ $l_{\mathrm{f}}$ と気孔の寄与による項 $d_{\mathrm{p}}$ の和で与えられる.

$$
l_{\mathrm{r}}=l_{\mathrm{f}}+d_{\mathrm{p}}
$$

(10)式及び(11)式を(12)に代入して整理すると

$$
\frac{1}{\sigma_{\mathrm{r}}^{2}}=\left(\frac{Y}{K_{\mathrm{IC}}}\right) d_{\mathrm{p}}+\left(\frac{Y}{4 \pi}\right)\left(\frac{1}{\gamma K_{\mathrm{IC}}}\right)\left(\frac{\sigma_{0}^{2}}{2 E_{0}}\right)
$$

となる.（13) 式の右辺第 2 項中の $\sigma_{0}{ }^{2} / 2 E_{0}$ は破壊する直前ま でに蓄えられた弾性歪みエネルギーに相当する.

図 7 は縦軸に残存強度の 2 乗の逆数 $1 / \sigma_{\mathrm{r}}{ }^{2}$ を横軸に破壊する までに蓄えられた弾性ひずみエネルギー $\sigma_{0}^{2} / 2 E_{0}$ をとって整理

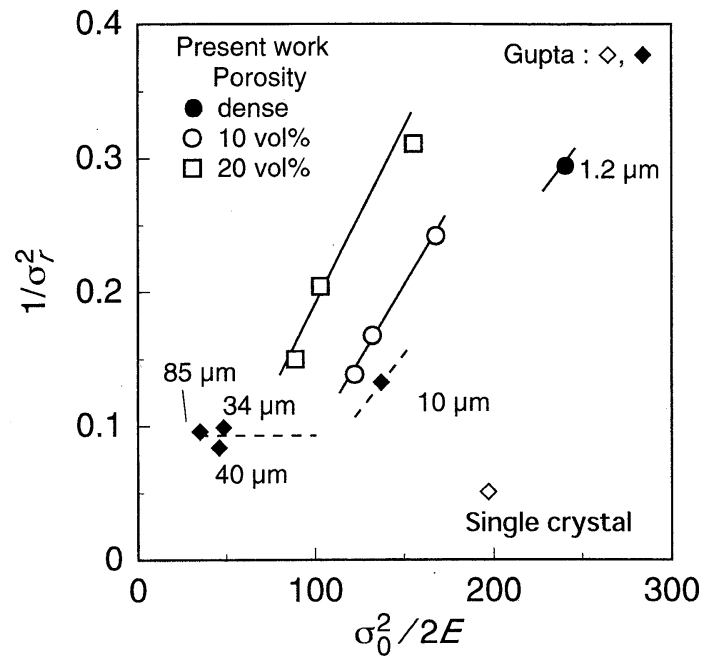

Fig. 7. Relation between the reciprocal of squared survival strength and elastic strain energy stored up to thermal shock fracture. Values of $\mu \mathrm{m}$ in a figure are grain sizes.

したものである. 残存強度と破壊起点での亀裂の大きさ $l_{\mathrm{r}}$ の 間には，(11)式のような関係があるので, 縦軸は熱衝撃破壊 をした後の亀裂長さに対応する，すなわち，緻密試料，気孔率 が $10 \%$ 及び $20 \%$ 試料について, 残存強度の 2 乗の逆数と丕み エネルギーの間には一定の関係が得られた. (13)式の右辺第 1 項は気孔の存在と関連する部分で, $d_{\mathrm{p}}$ は気孔率が $10 \%$ より $20 \%$ の方が大きくなるため, 図 7 中の直線関係が緻密試料, 気孔 率10\%更に $20 \%$ となるに従って上方に移行したものと考えら れる。

同図には緻密試料での Gupta の結果4)から推測した值もプ ロットした. Guptaの粒径 $10 \mu \mathrm{m}$ の值は, 本研究での緻密試料 である粒径が $1.2 \mu \mathrm{m}$ の值の延長線上にある。しかし，Gupta の $34,40 \mu \mathrm{m}$ 及び $85 \mu \mathrm{m}$ 粒径での值は，これらの傾向とは異な り，熱衝撃破壊までに蓄えられた弾性歪みエネルギーが変化し ても, 残存強度の 2 乗の逆数 $1 / \sigma_{\mathrm{r}}^{2}$ は一定の值を示した.

図 7 の整理のもとになった，(9)式は内在する亀裂の長さ $l_{0}$ が小さい試料について導かれたものである. 緻密試料での内在 する亀裂の大きさは結晶粒径に対応していると考えられる．す なわち, 結晶粒径が $34,40,85 \mu \mathrm{m}$ と大きい試料の場合には内 在する亀裂が大きくなり, 図 7 のような整理をするもとに なった (9) 式を満足していないため, 著者らの緻密試料及び Guptaの結晶粒径が $10 \mu \mathrm{m}$ の試料での值の傾向から外れたもの と推測している.

\section{4. 結 論}

気孔を含んだアルミナセラミックスの熱衝撃破壊挙動を測定 し，以下のような結果を得た。

（1）臨界温度差 $\Delta T_{\mathrm{c}}$ は気孔率の大きい方が高くなったが， 臨界温度差 $\Delta T_{\mathrm{c}}$ に対する気孔径の影響は認められなかった。

（2）水中急冷法による熱衝撃破壊試験では気孔率の大きい 試料の方が気孔の発生が多くなるため，断熱効果が顕著にな り， $\Delta T_{\mathrm{c}}$ が上昇したものと推測される.

（3）熱衝撃破壊後の残存強度は気孔径が大きくなると増大 したが，最大気孔径が $20 \mu \mathrm{m}$ 以上では増加の割合が小さくなっ た.

（4）熱衝撃破壊後の残存強度の低下割合は, 最大気孔径が 
$20 \mu \mathrm{m}$ 以上では気孔率の大きい試料の方が小さくなった.

（5）気孔率が一定の試料では, 熱衝撃破壊後の残存強度の 逆数の 2 乗 $\left(1 / \sigma_{\mathrm{r}}{ }^{2}\right)$ と破壊するまでに蓄えられた弾性歪み工 ネルギー $\left(\sigma_{0}^{2} / 2 E_{0}\right)$ の間には一定の関係が得られた。

\section{文献}

1) Davidge, R. W. and Tappin, G., Trans. Br. Soc., 66, 405-22 (1967).

2) Hasselman, D. P. H., J. Am. Ceram. Soc., 52, 600-04 (1969).

3) Hasselman, D. P. H., J. Am. Ceram. Soc., 53, 490-95 (1970).

4) Gupta, T. K., J. Am. Ceram. Soc., 55, 249-53 (1972).

5) Ashizuka, M., Easler, T. E. and Bradt, R. C., J. Am. Ceram. Soc., 66, 542-50 (1983).

6) Coble, R. L. and Kingery, W. D., J. Am. Ceram. Soc., 38, 33-37 (1955).

7) Katoh, S. and Ohkuda, H., Reports of the National Industrial Research Institute of Nagoya, 8, 353-59 (1959) [in Japanese].

8) Smith, R. D., Anderson, H. U. and Moore, R. E., Am. Ceram. Soc. Bull., 55, 979-82 (1976).

9) Ziegler, G. and Heinrich, J., Ceram. Int., 6, 25-30 (1980).

10) Arato, T., Nakamura, K. and Sobue, M., J. Ceram. Soc. Japan (Seramikkusu Ronbunshi), 97, 803-11 (1989) [in Japanese].

11) Ashizuka, M., Eiichi, I., Matsushita, T. and Hisanaga, M., J. Ceram. Soc. Japan, 109, 554-59 (2002) [in Japanese].
12) Niihara, K., Singh, J. P. and Hasselman, D. P. H., J. Mater. Sci., 17, 2553-59 (1982).

13) King, C. Y. and Webb, W. W., J. Appl. Phys., 42, 2386-95 (1971).

14) Oguma, M., Fairbanks, C. J. and Hasselman, D. P. H., J. Am. Ceram. Soc., 70, C2-3 (1987).

15) Sakuma, T., Iwata, U. and Takaku, H., Transaction of the Japan Society of Mechanical Engineering, Series B, 57, 2741-46 (1991) [in Japanese].

16) Japanese Industrial Standard, JIS R1648 (2002) [in Japanese].

17) Manson, S. S., Machine Design, 30, 114-20 (1958).

18) Mai, Y. W., J. Am. Ceram. Soc., 59, 491-94 (1976).

19) Becker, P. F., Lewis, D., III, Carman, K. R. and Gonzalez, A. C., Am. Ceram. Soc. Bull., 59, 542-48 (1980).

20) Singh, J. P, Tree, Y. and Hasselman, D. P. H., J. Mater. Sci., 16, 2109-18 (1981).

21) "JSME Heat Transfer Handbook," Ed. by The Japan Society of Mechanical Engineering (1993) pp. 160-61 [in Japanese].

22) “Thermophysical Properties Handbook," Ed. by Japan Society of Thermophisical Properties, Yokendo (1990) pp. 176-77 [in Japanese].

23) Kunii, T., Chem. Eng., 25, 891-98 (1961) [in Japanese].

24) Saegusa, T., Kamata, K., Iida, Y. and Wakao, N., Chem. Eng., 37, 811-14 (1973) [in Japanese]. 